\title{
The effect of forage quality and level of feeding on digestibility and gastrointestinal transit time of oat straw and alfalfa given to ponies and donkeys
}

\author{
R. A. Pearson ${ }^{1 *}$, R. F. Archibald ${ }^{1}$ and R. H. Muirhead ${ }^{2}$ \\ ${ }^{1}$ Centre for Tropical Veterinary Medicine and ${ }^{2}$ Department of Veterinary Clinical Studies, University of Edinburgh, Easter \\ Bush, Roslin, Midlothian EH25 9RG, Scotland, UK
}

(Received 14 April 2000 - Revised 2 November 2000 - Accepted 13 December 2000)

\begin{abstract}
Four donkeys and four ponies were fed molassed dehydrated alfalfa or oat straw, either ad libitum or restricted to about $70 \%$ ad libitum intake in a Latin-square design for four periods of $21 \mathrm{~d}$. Measurements of apparent digestibility and gastrointestinal transit time were made on the last $7 \mathrm{~d}$ of each period. When the forages were provided ad libitum, all animals ate significantly $(P<0 \cdot 01)$ more of the alfalfa than of the oat straw. Ponies consumed significantly $(P=0 \cdot 007)$ more of both diets per unit live weight than donkeys. Higher apparent digestibilities of dietary DM, energy and fibre fractions were seen in donkeys, at both levels of feeding, compared with the ponies. This partly compensated for the lower intakes by the donkeys when fed ad libitum. When intake of alfalfa was restricted, the apparent digestibility of DM was higher compared with the corresponding values when fed ad libitum, but the reverse was true for straw. This may be because restriction of a low-quality diet reduced selection of the more digestible parts of the forage. Donkeys and ponies consumed more energy and protein than required when fed alfalfa ad libitum. Both oat straw treatments provided insufficient protein to meet the predicted requirements of ponies and donkeys. Straw intakes ad libitum exceeded the estimated energy requirement for ponies by $34-51 \%$, but donkey energy requirements were only just met. When the amount of straw offered was restricted, $78-90 \%$ of the estimated energy requirement for donkeys was met compared with $90-105 \%$ for the ponies.
\end{abstract}

Apparent digestibility: Forage intake: Equids

Donkeys are an important source of power for transport and crop production in smallholder agriculture in tropical countries. For most of the year they are fed on crop residues and mature bush grasses of poor nutrient quality, each being low in $\mathrm{N}$ and with a high fibre content. Better quality forages, such as alfalfa, are available in many areas, but are expensive (Pearson, 1998). Ponies often fare better, but, even in temperate areas, their staple rations are often poor quality hay and straw diets, which are low in N. In order to determine the quantity of nutrients donkeys and ponies can obtain from both poor- and good-quality forages, it is important to know how much they consume and how well they digest these feeds when given them either ad libitum or when they receive a restricted ration.

Comparative studies (Pearson \& Merritt, 1991) of the voluntary food intakes of donkeys and ponies fed moderate- or poor-quality roughage diets (meadow hay and barley straw respectively) have shown that donkeys tend to consume less $\mathrm{DM} / \mathrm{d}$. As a result, they have a slower rate of passage of digesta through the gastrointestinal tract and, as a consequence, have a higher apparent digestibility of both organic matter and fibre fractions than has been measured in ponies. Greater intakes by ponies fed these forages seemed to compensate for the measured differences in the digestibility of feed components between the donkeys and the ponies when they were allowed access ad libitum (Pearson \& Merritt, 1991). The results suggested that both species obtain similar quantities of nutrients from these diets when offered ad libitum (Pearson \& Merritt, 1991) by two seemingly different strategies. However, nutrient intake was at or below that needed to sustain live weight (LW). It is not clear whether ponies and donkeys would continue to show these differences in intake and nutrient digestibility if they were given better quality forage diets that provided nutrients in a more accessible form. For example, would feeding strategies change and

\footnotetext{
Abbreviations: CP, crude protein; DE, digestible energy; LW, live weight; MRT, mean retention time; NDF, neutral-detergent fibre.

* Corresponding author: Dr R. Anne Pearson, fax + 44131445 5099, email anne.pearson@ed.ac.uk
} 
would the relative differences in intake and digestibility between the two species disappear if the animals were provided with good quality forages?

The ability of Thoroughbreds, Highland ponies, donkeys and Shetland ponies to digest forage diets of different fibre content (different proportions of alfalfa and oat straw) was investigated by Cuddeford et al. (1995). When the animals were fed a restricted ration, estimated to meet energy requirements for maintenance according to National Research Council (1989) recommendations, donkeys retained food residues in the gastrointestinal tract longer than did the other equids, irrespective of diet type. As a consequence, the donkeys digested fibre more effectively than did the other equids. All animals digested the components of the high-fibre diets less well than those of the low-fibre diets (Cuddeford et al. 1995). However, since the animals in the study were fed to meet energy requirements, DM intakes were higher when they were fed low-quality diets compared with when they were fed better quality diets, making it difficult to distinguish between the effects of diet quality and DM intake on nutrient digestibility.

In order to determine the effect of feeding level on the quantity of nutrients donkeys and ponies can obtain from poor- and good-quality forages, this present study investigated the relationships between diet quality, food intake, digestibility and gastrointestinal transit time of two forages in donkeys and ponies. The forages offered were oat straw and alfalfa. Preliminary results of part of this study have been reported by Pearson et al. (1998). The results will help determine recommendations for feeding these animals particularly where forage is the only source of nutrients available.

\section{Material and methods}

\section{Experimental design}

Short-chopped $(10-15 \mathrm{~cm})$, molassed $(20 \mathrm{~g} / \mathrm{kg})$ oat straw and short-chopped $(10-15 \mathrm{~cm})$ molassed $(20 \mathrm{~g} / \mathrm{kg})$ dehydrated alfalfa produced by Dengie Crops Ltd, Maldon, Essex, were offered to donkeys and ponies either ad libitum or in restricted amounts (70\% intake ad libitum) in $4 \times 4$ Latin-square design. Each animal received each of the four dietary treatments in turn over four $21 \mathrm{~d}$ periods and in each period, one donkey and one pony received each diet. The compositions of the two forages (Table 1) were determined by standard methods (Association of Official

Table 1. Composition of diets offered to donkeys and ponies (Mean values with their standard errors for four samples of each diet)

\begin{tabular}{lcclcc}
\hline & \multicolumn{2}{c}{ Alfalfa } & & \multicolumn{2}{c}{ Oat straw } \\
\cline { 2 - 3 } & Mean & SE & & Mean & SE \\
\hline DM (g/kg) & 937 & 8.3 & & 936 & 9.3 \\
Organic matter (g/kg DM) & 913 & 3.4 & & 948 & 7.7 \\
Neutral-detergent fibre (g/kg DM) & 443 & 19.6 & & 715 & 21.1 \\
Acid-detergent fibre (g/kg DM) & 339 & 23.7 & & 487 & 20.9 \\
Crude protein (g/kg DM) & 146 & 5.5 & & 38.8 & 4.52 \\
Gross energy (MJ/kg DM) & 17.6 & 0.21 & & 17.7 & 0.26 \\
\hline
\end{tabular}

Analytical Chemists, 1990) after sub-sampling diets offered daily.

\section{Animals and their management}

The experiment was carried out between June and September 1994 at the Centre for Tropical Veterinary Medicine, Edinburgh, Scotland, UK. Four adult donkeys (mean weight $189 \mathrm{~kg}$ ) and four adult Welsh-cross ponies (mean weight $250 \mathrm{~kg}$ ) were housed in individual stalls (about $1.4 \mathrm{~m} \times 2.5 \mathrm{~m}$ ) next to each other in a barn. The barn was open on one side so they received natural daylight. Urine was allowed to drain down channels in the floor away from the area where faeces were voided. Clean drinking water was always available from individually monitored supplies. The daily ration for these animals was divided into four equal meals and given at 08.00, 12.00, 16.00 and 20.00 hours in deep-sided troughs to reduce spillage. Any food refusals and uneaten spillage were collected at 08.00 hours each day before fresh food was offered. Each animal was walked in hand for $30 \mathrm{~min} / \mathrm{d}$. The daily intakes of feed were assessed before the experiment when animals were fed each diet in turn, ad libitum for a 2week period. These daily intakes were re-evaluated during the experiment based on the voluntary intake of those animals receiving the ad libitum treatments. Animals on the ad libitum treatments were offered feeds daily in sufficient quantity to enable them to refuse at least $200 \mathrm{~g} \mathrm{DM} / \mathrm{kg} \mathrm{DM}$ of feed offered. The amount of feed offered was adjusted daily on the basis of the intake of the previous day to achieve the target refusal rate.

\section{Measurements and rate of passage markers}

Each animal was weighed at the start of the experiment and twice weekly thereafter to the end of the experimental period. For the first $14 \mathrm{~d}$ of each period, the animals were allowed to adapt to the new diet. During the final $7 \mathrm{~d}$, measurements of food intake (from the amount of DM in feed and in each individual's feed refusals, with trough and floor refusals determined separately) and faecal output were made. Mean retention time (MRT) of two indigestible food markers, Co-EDTA, a liquid phase marker, and $\mathrm{Cr}$ mordanted hay fibre ( $\mathrm{Cr}$-fibre), a solid phase marker, were measured using the techniques described by Pearson \& Merritt (1991). These markers have been found to be satisfactory for studying rate of passage of digesta in herbivores eating high-fibre rations (e.g. Uden et al. 1982). A single dose of each marker was administered at 23.00 hours on the day preceding the collection period (day 13). Cr-fibre (70 g) was mixed with five 'Polo mints' (Nestle, York, UK) to increase palatability, pelleted, and given by hand to each animal. Co-EDTA $(100 \mathrm{ml})$ was given as a drench by syringe at the back of the throat. Feeding of the appropriate diet was resumed immediately after the animals had been given the markers.

Complete faecal collections were made at regular intervals from 23.00 hours on day 14 (when markers were administered) for $7 \mathrm{~d}$ until the end of the period (08.00 hours on the morning of day 22). For estimation of MRT, faeces were collected from each animal at 9, 11, 13, 
$15,17,20,23,31,33,35,37,39,41,46,54,57,60,64,69$, $80,84,88,93,104,112,128,136,152,160$ and $176 \mathrm{~h}$ after marker administration. Individual faecal collections were weighed, thoroughly mixed and a sub-sample taken for the determination of DM and marker concentrations. A further sample from each collection $(20 \mathrm{~g} / \mathrm{kg})$ was stored frozen before pooling over the $7 \mathrm{~d}$ period for each animal for subsequent analysis. All food and faecal samples were dried in a forced-draught oven at $60^{\circ} \mathrm{C}$ to constant weight and then ground through a $1 \mathrm{~mm}$ screen before analysis. Acid-detergent fibre, neutral-detergent fibre (NDF), crude protein (CP), gross energy and organic matter were determined according to the methods reported by the Association of Official Analytical Chemists (1990).

\section{Calculations and statistical analyses}

Apparent digestibility coefficients were calculated from DM intakes and faecal DM outputs over the $7 \mathrm{~d}$ collection periods:

Apparent digestibility of DM

= wt of food DM - wt of faeces DM/wt of food DM.

Similar calculations were made to calculate the apparent digestibility of NDF, acid-detergent fibre, $\mathrm{CP}$, organic matter and gross energy. The MRT of Cr-fibre and CoEDTA were calculated using the methods described by Pearson \& Merritt (1991). Digestible energy (DE) and digestible $\mathrm{CP}$ intakes were expressed per unit LW to enable comparisons between species to be made.

The formula used to estimate maintenance requirements for $\mathrm{DE}(\mathrm{MJ})$ was:

$$
\mathrm{DE}=4.184(0.975+0.021 \times \mathrm{M}),
$$

where $\mathrm{M}$ is the live weight. This formula was derived from metabolic studies with horses (National Research Council, 1989). For ponies:

$$
\mathrm{DE}=0.465 \times \mathrm{M}^{0.75}
$$

a formula developed by Ellis \& Lawrence (1980) for use with native ponies in the UK.

Digestible protein requirements for maintenance $(\mathrm{g} / \mathrm{d})$ were estimated using the formula $0 \cdot 6 \times \mathrm{M}$ (National Research Council, 1989). In view of the lack of information specifically available on the energy and protein requirements of donkeys, the assumption has been made that energy and protein requirements for donkeys can be estimated using the same formulas. This may overestimate requirements for donkeys.

The experiment was a change-over design comparison using two Latin-squares, one for each species. The data obtained were subjected to an analysis of variance using GENSTAT 5 (release 3.4, 1993; Lawes Agricultural Trust, Rothamsted Experimental Station, Harpenden, Bucks, UK). In the analysis, the total sum of squares was partitioned into three strata representing variation between animals and periods together with an animal $\times$ period interactions. Overall species effects were estimated and tested from the between-animal stratum $($ d.f. $=6)$. Diet effects and species $\times$ diet interactions were estimated and tested from the animal $\times$ period stratum $($ d.f. $=15)$. Residual effects of dietary treatment were tested for carry-over using covariance analysis and were not found to be significant for any of the measurements made.

\section{Results \\ Temperature and relative humidity}

Ambient temperatures and humidities were monitored in the animal shed. The readings for maximum, minimum and dry bulb temperatures and relative humidity were taken daily at $10.00 \mathrm{~h}$. The mean values of the daily values recorded during each collection period ( $n 7)$ were calculated. The ranges of the mean values were $14 \cdot 6-19 \cdot 6^{\circ} \mathrm{C}$ for maximum daily temperature, $7 \cdot 2-11 \cdot 4^{\circ} \mathrm{C}$ for minimum daily temperature, $9 \cdot 4-13 \cdot 7^{\circ} \mathrm{C}$ for dry bulb temperature and $83-92 \%$ for relative humidity.

\section{Period effects}

The amount of experimental variation that could be accounted for by time period effects (i.e. time of feeding relative to the time from the start of the experiment) was not significant.

\section{Food and water intake}

Ponies consumed significantly $(P<0.01)$ more feed and water than the donkeys (Table 2). During the experiment, the restricted intakes of alfalfa and oat straw by the ponies averaged 43 and $71 \%$ of their intake ad libitum respectively. Similarly, the restricted intakes of alfalfa and oat straw by the donkeys averaged $51 \%$ and $86 \%$ respectively. The voluntary intake of alfalfa by two ponies and one donkey increased continuously and that of oat straw by one donkey decreased continuously over the $21 \mathrm{~d}$ periods they were on these treatments. These occurrences probably accounted for the failure to achieve the target intakes for the restricted treatments of $70 \%$ of intake ad libitum.

\section{Apparent digestibility of nutrients}

Donkeys had significantly $(P<0.05)$ higher apparent digestibilities for the main dietary components of the forages (Table 3) compared with those measured in ponies. The differences were more pronounced when the good quality, alfalfa diet was provided than when the poorer quality straw diet was fed.

The apparent digestibilities of DM and energy in alfalfa were higher $(P<0.001)$ than that of the straw in both species, with the digestibility of this feed being greater in donkeys when intake was restricted $(P<0.05)$. The opposite effect occurred when oat straw was fed. The apparent digestibilities of both DM and energy were higher when oat straw was offered ad libitum than when it was fed in restricted amounts $(P<0 \cdot 05)$. These differences were reflected in the values for NDF and acid-detergent fibre digestibilities for donkeys $(P<0 \cdot 05)$. For straw-fed 
Table 2. Daily DM, digestible energy (DE), digestible crude protein (CP) and voluntary water intakes and average live weight (LW) of ponies and donkeys fed alfalfa $(\mathrm{A})$ or oat straw $(\mathrm{OS})$ ad libitum $(\mathrm{AL})$ or restricted $(\mathrm{R})$ to about 0.70 of ad libitum intake $\dagger$

(Mean values with standard errors of the difference for four donkeys and four ponies)

\begin{tabular}{|c|c|c|c|c|c|c|c|c|}
\hline & \multirow[b]{2}{*}{ Species of equid } & \multicolumn{2}{|r|}{$A$} & \multicolumn{2}{|c|}{ OS } & \multirow[b]{2}{*}{ Mean } & \multicolumn{2}{|c|}{ Statistical significance of effects } \\
\hline & & $A L$ & $\mathrm{R}$ & $A L$ & $\mathrm{R}$ & & Effect & $P$ value \\
\hline \multicolumn{9}{|l|}{ Daily intake of: } \\
\hline \multirow[t]{4}{*}{ DM (g/kg LW) } & Pony & $38 \cdot 6$ & $17 \cdot 9$ & $24 \cdot 0$ & $17 \cdot 0$ & 24.4 & Species & 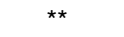 \\
\hline & Donkey & $26 \cdot 7$ & $15 \cdot 0$ & $16 \cdot 3$ & 14.4 & $18 \cdot 1$ & Diet & $\star \star \star *$ \\
\hline & Mean & $32 \cdot 7$ & $16 \cdot 4$ & $20 \cdot 1$ & $15 \cdot 7$ & & Species $\times$ diet & * \\
\hline & SED 2.56‡ & & SED $2 \cdot 30 \S$ & & SED 1.62\| & SED 1.63ף & & \\
\hline \multirow{4}{*}{$\mathrm{DM}\left(\mathrm{g} / \mathrm{kg} \mathrm{LW} \mathrm{LW}^{0.75}\right)$} & Pony & $155 \cdot 0$ & $70 \cdot 2$ & $94 \cdot 7$ & 67.5 & 96.9 & Species & $\star \star \star \star ~$ \\
\hline & Donkey & $100 \cdot 0$ & 54.9 & $59 \cdot 8$ & $52 \cdot 7$ & $66 \cdot 9$ & Diet & $\star \star \star *$ \\
\hline & Mean & $127 \cdot 6$ & 62.5 & $77 \cdot 3$ & $60 \cdot 1$ & & Species $\times$ diet & * \\
\hline & SED 9.10‡ & & SED $8.67 \S$ & & SED $5 \cdot 14 \|$ & SED 6.13ף & & \\
\hline \multirow[t]{4}{*}{$\mathrm{DE}(\mathrm{kJ} / \mathrm{kg} \mathrm{LW})$} & Pony & 373 & 169 & 158 & 111 & 203 & Species & \\
\hline & Donkey & 284 & 171 & 132 & 100 & 172 & Diet & $\star \star * *$ \\
\hline & Mean & 329 & 170 & 145 & 105 & & Species $\times$ diet & \\
\hline & SED $30 \cdot 88 \ddagger$ & & SED $27 \cdot 3 \S$ & & SED $19 \cdot 0 \|$ & SED 19.3ף & & \\
\hline \multirow[t]{4}{*}{ Digestible CP (g/kg LW) } & Pony & $2 \cdot 36$ & $1 \cdot 12$ & 0.04 & -0.09 & 0.86 & Species & \\
\hline & Donkey & 1.90 & 1.64 & 0.08 & -0.17 & 0.86 & Diet & * \\
\hline & Mean & $2 \cdot 13$ & 1.38 & 0.06 & -0.13 & & Species $\times$ diet & \\
\hline & SED 0.694‡ & & SED $0.727 \S$ & & SED 0.292\| & SED 0.514ף & & \\
\hline \multirow[t]{4}{*}{ Water (I/kg DM) } & Pony & 4.35 & 4.74 & 3.77 & 4.52 & 4.35 & Species & * \\
\hline & Donkey & $3 \cdot 21$ & $4 \cdot 31$ & $3 \cdot 18$ & $3 \cdot 80$ & $3 \cdot 62$ & Diet & \\
\hline & Mean & 3.78 & 4.52 & 3.48 & $4 \cdot 16$ & & Species $\times$ diet & \\
\hline & SED $0.495 \ddagger$ & & SED $0.472 \S$ & & SED $0.303 \|$ & SED 0.304ף & & \\
\hline \multirow[t]{4}{*}{ Water (ml/kg LW) } & Pony & 171 & 80 & 89 & 77 & 104 & Species & * \\
\hline & Donkey & 87 & 64 & 52 & 55 & 64 & Diet & ** \\
\hline & Mean & 129 & 72 & 70 & 66 & & Species $\times$ diet & * \\
\hline & SED $16 \cdot 6 \ddagger$ & & SED $13 \cdot 7 \S$ & & SED $11.7 \|$ & SED 9.79 & & \\
\hline \multirow[t]{4}{*}{ Live weight $(\mathrm{kg})$} & Pony & 266 & 241 & 254 & 251 & 253 & Species & * \\
\hline & Donkey & 197 & 182 & 182 & 178 & 185 & Diet & $\star \star \star *$ \\
\hline & Mean & 231 & 212 & 218 & 214 & & Species $\times$ diet & \\
\hline & SED 26.9‡ & & SED $4.68 \S$ & & SED $26 \cdot 6 \|$ & SED $3.31 \rrbracket$ & & \\
\hline
\end{tabular}

${ }^{\star} P<0.05,{ }^{* *} P<0.01,{ }^{* * *} P<0.001$.

† For details of diets and procedures, see Table 1 and p. 600 respectively.

$\ddagger$ SED for comparison between two means for different species of equid.

$\S$ SED for comparison between two means for the same species of equid.

$\|$ SED for comparison between overall means for equine species.

ๆ SED for comparison between overall means for diet types.

ponies, NDF digestibility was higher when straw intake was restricted although this difference was not significant.

\section{Rate of passage of feed residues}

MRT of the solid and liquid phases of the digesta are reported in Table 4 . In all cases, $\mathrm{Cr}$-fibre $(P<0.001)$ and Co-EDTA $(P=0.04)$ passed through the gastrointestinal tract of ponies more quickly than through the gastrointestinal tract of donkeys. Significantly $(P<0.01)$ longer MRT were measured in both species fed restricted amounts of alfalfa compared with values recorded when it was fed ad libitum. When fed oat straw, the ponies had longer MRT when it was restricted, however, donkeys retained straw particles in their gastrointestinal tract longer when they were fed ad libitum.

\section{Live weight and intake of digestible nutrients}

Although ponies consumed more DM than donkeys, in terms of DE intake $(\mathrm{kJ} / \mathrm{kg} \mathrm{LW})$, a comparison between the species showed that the differences were small (Table 2), reflecting the compensating effect of the higher apparent digestibility of organic matter in donkeys than in ponies
(Table 3). Significant differences in LW were seen between treatments with the lowest weight on the restricted straw diets and highest on alfalfa ad libitum (Table 2).

Daily intakes of DE and digestible CP were compared with estimated daily requirements for these nutrients. Although the ponies consistently consumed more energy relative to their requirements than donkeys, the difference between species was only significant $(P<0.05)$ when the comparisons were based on the Ellis \& Lawrence (1980) standards. Intakes of alfalfa ad libitum by ponies exceeded estimated requirement 3.2-3.6-fold and intake in donkeys exceeded requirement $2 \cdot 2-3 \cdot 1$-fold. LW was the highest on this diet for both species (Table 2). Restricting the intake of alfalfa almost halved the DE intake:DE requirement ratio of ponies, $(1 \cdot 3-1 \cdot 6)$, less so in donkeys $(1 \cdot 2-1 \cdot 5)$ and was reflected in a lower LW than on the alfalfa ad libitum (Table 2).

Straw intakes ad libitum exceeded pony energy requirements by between 34 and $51 \%$, but donkey energy requirements were only just met. Limiting access to straw had less effect on DE intakes. Pony LW on this diet was higher and donkey LW was the same as on the restricted alfalfa treatment (Table 2), which may reflect the more bulky nature of the straw diet and hence a greater gut-fill. 
Table 3. Mean apparent digestibility of DM, organic matter (OM), gross energy (GE), crude protein (CP), acid-detergent fibre (ADF) and neutraldetergent fibre (NDF) in ponies and donkeys given alfalfa (A) or oat straw (OS) ad libitum (AL) or restricted (R) to about 0.70 of ad libitum intake† (Mean values with standard errors of the diffrence for four donkeys and four ponies)

\begin{tabular}{|c|c|c|c|c|c|c|c|c|}
\hline & \multirow[b]{2}{*}{ Species of equid } & \multicolumn{2}{|r|}{ A } & \multicolumn{2}{|r|}{ OS } & \multirow[b]{2}{*}{ Mean } & \multicolumn{2}{|c|}{ Statistical significance of effects } \\
\hline & & $A L$ & $\mathrm{R}$ & $A L$ & $\mathrm{R}$ & & Effect & $P$ value \\
\hline \multicolumn{9}{|c|}{$\begin{array}{l}\text { Apparent digestibility } \\
\text { coefficients: }\end{array}$} \\
\hline \multirow[t]{4}{*}{ DM } & Pony & 0.58 & 0.58 & 0.43 & 0.40 & 0.50 & Species & * \\
\hline & Donkey & 0.63 & 0.66 & 0.50 & 0.43 & 0.55 & Diet & 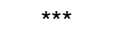 \\
\hline & Mean & 0.60 & 0.62 & 0.47 & 0.42 & & Species $\times$ diet & \\
\hline & SED $0.028 \ddagger$ & & SED $0.023 \S$ & & SED $0.019 \|$ & SED $0.017 \rrbracket$ & & \\
\hline \multirow[t]{4}{*}{$\mathrm{OM}$} & Pony & 0.58 & 0.58 & 0.44 & 0.43 & 0.51 & Species & * \\
\hline & Donkey & 0.63 & 0.66 & 0.49 & 0.45 & 0.56 & Diet & $\star \star * *$ \\
\hline & Mean & 0.60 & 0.62 & 0.47 & 0.44 & & Species $\times$ diet & \\
\hline & SED 0.026‡ & & SED $0.022 \S$ & & SED 0.017\| & SED 0.015ף & & \\
\hline \multirow[t]{4}{*}{ GE } & Pony & 0.54 & 0.54 & 0.41 & 0.37 & 0.46 & Species & * \\
\hline & Donkey & 0.60 & 0.63 & 0.46 & 0.39 & 0.52 & Diet & $\star \star \star *$ \\
\hline & Mean & 0.57 & 0.58 & 0.43 & 0.38 & & Species $\times$ diet & \\
\hline & SED $0.028 \ddagger$ & & SED $0.023 \S$ & & SED $0.020 \|$ & SED 0.016ף & & \\
\hline \multirow[t]{4}{*}{$\mathrm{CP}$} & Pony & 0.67 & 0.68 & -0.03 & -0.11 & 0.30 & Species & * \\
\hline & Donkey & 0.75 & 0.81 & 0.09 & -0.10 & 0.38 & Diet & $\star \star * *$ \\
\hline & Mean & 0.71 & 0.74 & 0.03 & -0.10 & & Species $\times$ diet & \\
\hline & SED $0.089 \ddagger$ & & SED $0.099 \S$ & & SED $0.024 \|$ & SED 0.070 & & \\
\hline \multirow[t]{4}{*}{ ADF } & Pony & 0.37 & 0.39 & 0.46 & 0.43 & 0.41 & Species & * \\
\hline & Donkey & 0.47 & 0.50 & 0.51 & 0.46 & 0.48 & Diet & \\
\hline & Mean & 0.42 & 0.44 & 0.48 & 0.45 & & Species $\times$ diet & \\
\hline & SED $0.033 \ddagger$ & & SED $0.030 \S$ & & SED $0.020 \|$ & SED $0.021 \rrbracket$ & & \\
\hline \multirow{4}{*}{ NDF } & Pony & 0.38 & 0.42 & 0.47 & 0.48 & 0.43 & Species & * \\
\hline & Donkey & 0.47 & 0.54 & 0.51 & 0.46 & 0.49 & Diet & \\
\hline & Mean & 0.43 & 0.48 & 0.49 & 0.45 & & Species $\times$ diet & \\
\hline & SED $0.038 \ddagger$ & & SED $0.033 \S$ & & SED 0.026\| & SED 0.023ף & & \\
\hline
\end{tabular}

${ }^{\star} P<0.05,{ }^{\star *} P<0.01,{ }^{\star * \star} P<0.001$.

† For details of diets and procedures, see Table 1 and p. 600 respectively.

$\ddagger$ SED for comparison between two means for different species of equid.

$\S$ SED for comparison between two means for the same species of equid.

\| SED for comparison between overall means for equine species.

ๆ SED for comparison between overall means for diet types.

On the restricted straw diets, donkeys did not satisfy their energy needs, whereas ponies almost achieved an energy balance. When the amount of straw offered was restricted, 78 and $90 \%$ energy requirement was consumed by the donkeys compared with 94 and $105 \%$ by the ponies. LW were lowest on these dietary treatments in both species (Table 2).

When fed restricted amounts of straw, the animals were in negative protein balance and could not satisfy protein needs even when the straw was fed ad libitum. Unrestricted access to alfalfa provided nearly four times the protein requirement and more than 1.75 times the protein needs for both species when alfalfa was restricted. In the latter instance, donkeys obtained more digestible protein than ponies, presumably reflecting the higher protein digestibility coefficient with this species (Table 3 ).

Table 4. The mean retention time of Chromium-mordanted hay fibre (Cr-fibre) and cobalt-EDTA in the digestive tract of ponies and donkeys given alfalfa $(A)$ or oat straw (OS) ad libitum (AL) or restricted (R) to about 0.70 of ad libitum intake

\begin{tabular}{|c|c|c|c|c|c|c|c|c|}
\hline & \multirow[b]{2}{*}{ Species of equid } & \multicolumn{2}{|r|}{ A } & \multicolumn{2}{|r|}{ OS } & \multirow[b]{2}{*}{ Mean } & \multicolumn{2}{|c|}{ Statistical significance of effects } \\
\hline & & $\mathrm{AL}$ & $\mathrm{R}$ & $\mathrm{AL}$ & $\mathrm{R}$ & & Effect & $P$ value \\
\hline \multirow{5}{*}{$\begin{array}{l}\text { Mean retention time }(\mathrm{h}) \text { : } \\
\text { Cr-fibre }\end{array}$} & & & & & & & & \\
\hline & Pony & $21 \cdot 3$ & 30.5 & 31.5 & $36 \cdot 0$ & $29 \cdot 8$ & Species & $\star \star * *$ \\
\hline & Donkey & $32 \cdot 8$ & 39.8 & 44.3 & 38.3 & $38 \cdot 8$ & Diet & ** \\
\hline & Mean & $27 \cdot 0$ & $35 \cdot 1$ & 37.9 & $37 \cdot 1$ & & Species $\times$ diet & \\
\hline & SED 3.19 & & SED $3 \cdot 31 \S$ & & SED $1.40 \|$ & SED 2.34ף & & \\
\hline \multirow{4}{*}{ Co-EDTA } & Pony & $20 \cdot 5$ & 26.8 & 30.0 & 33.5 & 27.7 & Species & * \\
\hline & Donkey & $25 \cdot 3$ & 31.3 & $38 \cdot 0$ & $34 \cdot 0$ & $32 \cdot 1$ & Diet & $\star \star \star *$ \\
\hline & Mean & $22 \cdot 9$ & $29 \cdot 0$ & $34 \cdot 0$ & 33.8 & & Species $\times$ diet & \\
\hline & SED 2.73 & & SED $2 \cdot 35 \S$ & & SED $1 \cdot 82 \|$ & SED 1.66ף & & \\
\hline
\end{tabular}

${ }^{\star} P<0.05,{ }^{\star \star} P<0.01,{ }^{\star \star \star} P<0.001$.

† For details of diets and procedures, see Table 1 and p. 600 respectively.

† SED for comparison between two means for different species of equid.

$\S$ SED for comparison between two means for the same species of equine.

\| SED for comparison between overall means for equine species.

Il SED for comparison between overall means for diet types. 


\section{Discussion}

Daily voluntary DM intakes of the dehydrated alfalfa by the ponies $\left(155 \mathrm{~g} / \mathrm{kg} \mathrm{LW}^{0.75}\right)$ were higher than the range reported for dried alfalfa pellets, cubes or wafers (88138 g/kg LW ${ }^{0.75}$; Haenlein et al. 1966; Cymbaluk, 1990; Todd et al. 1995) and the range for alfalfa hays (75-122 g/ $\mathrm{kg} \mathrm{LW}^{0.75}$; Haenlien et al. 1966; Cymbaluk, 1990; Todd et al. 1995; Crozier et al. 1997; Dulphy et al. 1997a,b). Daily DM intakes of the dehydrated alfalfa by the donkeys $\left(100 \mathrm{~g} / \mathrm{kg} \mathrm{LW}^{0.75}\right)$ were higher than those reported in donkeys consuming grass and grass-legume-hay mixtures (67-88 g/kg LW ${ }^{0.95}$; Pearson \& Merritt, 1991; Tisserand et al. 1991; Mueller et al. 1994) and millet stover (60$77 \mathrm{~g} / \mathrm{kg} \mathrm{LW}^{0.75}$; Mueller et al. 1994). Intakes of the oat straw in donkeys and ponies in the present experiment were higher than intakes reported of barley straw $(37 \mathrm{~g} / \mathrm{kg}$ $\mathrm{LW}^{0.75}$ and $60 \mathrm{~g} / \mathrm{kg} \mathrm{LW}^{0.75}$; Pearson \& Merritt, 1991) and wheat straw $\left(57 \mathrm{~g} / \mathrm{kg} \mathrm{LW}^{0.75}\right.$ and $53 \mathrm{~g} / \mathrm{kg} \mathrm{LW}^{0.75}$; Tisserand et al. 1991) by donkeys and ponies respectively, but considerably less than the daily intakes of hays reported in the literature.

The high voluntary intakes of the oat straw and alfalfa in the present experiment compared with values in the literature may be due to seasonal effects on intake. The present experiment was undertaken in the summer months and it may be that forage intakes are higher in the summer than in the winter in temperate areas due to photoperiod effects. There is little information available on the effects of season on forage intake by equids, however Fuller et al. (1998) observed higher DE intakes by young ponies on long 'day-lengths' than on short 'day-lengths' in a study using simulated daylengths at constant temperatures.

Dulphy et al. (1997b), in a review of forage intakes by horses, observed that voluntary DM intake in horses was not influenced by $\mathrm{CP}$, crude fibre or NDF content and as a result it was difficult to predict voluntary intake of horses from the characteristics of ingested forages. They found intakes of straws were lower than those of other forages $(12-15 \mathrm{~g} / \mathrm{kg} \mathrm{LW}$ compared with intakes of grass hays of $17-21 \mathrm{~g} / \mathrm{kg} \mathrm{LW}$ and of lucerne hays of $21-23 \mathrm{~g} / \mathrm{kg} \mathrm{LW}$ ), which they attributed largely to organoleptic differences between the straw and the other forages (Dulphy et al. 1997b). They suggested predicted intakes of straws by horses should be lower than those of other forage types. The results of the present experiment suggest that the same situation also applies for forage intakes by ponies and donkeys.

The low CP content of the cereal straws (40 g/kg DM, present study) compared with other forages may be a contributing factor to the low intake of the straw diets by the donkeys and ponies in the present experiment, through inhibition of microbial digestion in the hindgut. Diets that contain $<80 \mathrm{~g} \mathrm{CP} / \mathrm{kg} \mathrm{DM}$ depress intake in ruminants, through their slow rates of fermentation in the rumen (Van Soest, 1994). Hyslop et al.(1997) showed that the microflora of equine hindgut had many characteristics of those in the rumen. They were as effective as rumen foregut microflora in digesting feed ingredients. Suhartanto et al. (1992) observed increased volatile fatty acid production in the caecum of ponies and donkeys following $\mathrm{N}$ supplementation of a wheat straw diet by ponies and donkeys and higher intake compared with that of unsupplemented straw. Other factors may contribute to reduced intakes by equids on cereal straws. Dulphy et al. (1997a) suggested low palatability was a factor, while the effects of extent of gut-fill of the digestive tract on the control of appetite are not well known (Ruckebusch, 1984) and warrant further investigation.

Generally the digestibility coefficients of the main dietary components of forages measured in donkeys are higher than those measured when the same feeds are fed to ponies or horses (e.g. Araújo et al. 1997). In the present study, differences were greater on the oat-straw diet than on the alfalfa diet, a similar observation to that seen in other comparative studies of digestion of straw and alfalfa diets by equids (Pearson \& Merritt, 1991; Pearson et al. 1992). The negative measurement of protein apparent digestibility may have resulted from high levels of endogenous $\mathrm{N}$ being present in the faeces. Izraely et al. (1989b) found that when donkeys were fed on wheat straw at maintenance, the amount of $\mathrm{N}$ recycled considerably exceeded that consumed in the food. The ability of donkeys to recycle urea effectively, up to $75 \%$ on wheat straw (Izraely et al. 1989a), may account for their ability to maintain DE intakes on diets with low CP contents, as low as $39 \mathrm{~g} / \mathrm{kg}$ $\mathrm{DM}$ in the present study.

The effect of level of feeding on digestibility of feed by the donkeys and ponies was influenced by forage type. The apparent digestibility of DM was higher for the oat-straw diet when it was fed ad libitum than when it was restricted, particularly in the donkeys. When the alfalfa diet was eaten by the donkeys the opposite effect of level of feeding was true and digestibility of the feed tended to be higher when intake was restricted. This effect was less noticeable in the ponies.

Improved selection offers an explanation for the improved digestibility of the oat straw when the diet was offered ad libitum. Feeding a low-quality diet ad libitum may enable selection of the more digestible fractions of the diet. Although the composition of feed refusals was not measured in the present experiment, evidence from other studies of donkeys fed cereal straw diets suggests that selection may play a significant role in the improved digestibility of straw when it is fed ad libitum to this species. Tisserand et al. (1991) found that on hay diets, donkeys ate more fibre and less nitrogenous matter than the ponies, but on straw diets they selected less fibre, particularly when the $\mathrm{N}$ content of the diet was low. They suggested that donkeys restrict their intake of fibre more than ponies when fed forages that are lignified (Tisserand et al. 1991). Van Soest (1994) suggested the relatively narrow muzzle of the donkey as compared with the horse indicates selectivity to be a characteristic of their feeding strategy. The level of feed excess may influence the amount of digestible nutrients available to equids. Fernandez-Rivera et al. (1994) found sheep fed on pearl millet (Pennisetum americanum) were able to select a more digestible diet if level of feed excess was at least $15 \%$ greater than voluntary intake. Savadogo et al. (2000) when feeding sheep sorghum stover advised that a very high feeding level, where only $53 \%$ was eaten was required to 
reach the maintenance level of digestible organic matter intake. However, it is rare in practice that donkeys would have access to such a surplus of crop residue from which to feed, since priority is usually given to supplementation of other livestock in many of the countries where donkeys are used for work (Pearson, 1998). Time allowed for feeding may also be important in diet selection by donkeys. Smith (1999) found that time of access to pasture influenced selection. Donkeys selected a more digestible diet (in terms of NDF, CP and in vitro digestibility) when allowed $23 \mathrm{~h}$ access to pasture than when allowed only $8 \mathrm{~h}$ access.

Cuddeford et al. (1995) found that when Thoroughbreds, Highland ponies, donkeys and Shetland ponies were fed a restricted ration to meet estimated energy requirements for maintenance, regardless of forage type, donkeys retained food residues in the gastrointestinal tract longer than did the other equids and consequently the donkeys digested fibre more effectively than did the other equids. The present study has confirmed this observation and suggests that differences between equid types also apply when equids are given alfalfa and oat straw diets ad libitum. Whether these differences in retention time are due to differences in anatomical or physiological differences between the species remains to be determined. Differences in water intakes exist between the two species. Donkeys consumed less water per unit DM and per unit LW than the ponies did, possibly reflecting their origins in a hot, semi-arid environment, and other differences. There may also be differences in the type and proportions of micro-organisms in the hindgut and hence in microbial activity between donkeys and ponies. Suhartanto et al. (1992) observed higher concentrations of volatile fatty acids in the caecal fluid of donkeys than in ponies on low $\mathrm{N}$ wheat straw-based diets and differences in the proportions of butyric and acetic acids which they suggested may account for differences in retention time and differences in fibre digestibility between the two species.

The lower voluntary intakes of straw and alfalfa, longer retention times and relatively higher digestibilities of feed by donkeys compared with the ponies seen in the present experiment may only apply to forage diets. Cuddeford \& Hyslop (1996) found that differences in feed intake and digestion strategy were not evident when both species were offered a high-quality fibre-based concentrate feedstuff $a d$ libitum.

Donkeys and ponies when offered the alfalfa forage ad libitum ate more than their calculated DE requirements. Similar observations were made by Cymbaluk (1990) in horses and Cuddeford \& Hyslop (1996) in donkeys and ponies offered grass and legume hays ad libitum. Hyslop et al. (1998) found that ponies consumed DE equivalent to approximately 2.5 times theoretical requirements when offered dehydrated grass or hay made from the same grass crop. Cuddeford \& Hyslop (1996) proposed that penned equids do not regulate their energy intake according to requirements in the short term. The results in the present experiment support this finding.

Differences in intakes of DE by donkeys and ponies were small, despite the higher DM intake of the ponies. This suggests that the better apparent digestibilities of nutrients by donkeys on forage diets compared with that of ponies enables them to compensate fairly successfully for their lower intakes of feed. The ponies' strategy appears to be to consume greater quantities of the feed with shorter retention times in the gastrointestinal tract and lower apparent digestibilities of nutrients, whereas the donkey appears more 'ruminant-like', with longer retention times of feed in the tract, lower intakes and better apparent digestibilities of nutrients. In situations where the forage supply is limited, the donkey would exploit the nutrients available more effectively than the pony could. Janis (1976) considered that equids generally, because of higher intakes, were at an advantage relative to ruminants when there is a plentiful supply of poor quality forage. However, in view of the fact the donkey seems to adopt a more 'ruminant-like' nutritional strategy with lower intakes and higher feed digestibilities, it is perhaps inappropriate to consider the donkey in the same terms as the horse and pony. It may be that the mechanisms of regulation of forage intake, which still have to be defined in detail for horses and ponies, are similar in donkeys, but the relative contributions of each mechanism to regulation of intake may be different in the two species.

\section{Conclusions}

This study has provided further evidence of the effect that type of forage and feeding level can have on the intake and digestibility of forages by equids. Good quality forages did not reduce the differences in the strategies employed by donkeys and ponies to obtain nutrients from poorer quality forages. On cereal straw diets, it appears better to feed $a d$ libitum, to allow for the possibility of some selection, to improve feeding value to the equids. On legume forages, restricting access can maximise digestibility of the dietary components, and prevent animals eating more than their requirement.

\section{Acknowledgements}

The study was carried out with financial support from the British Overseas Development Administration (now the Department for International Development), whose contribution is gratefully acknowledged. The authors thank I. Campbell, J. Hogg and P. Wright for care of the animals, E.A. Hunter for statistical advice and D. Cuddeford and J.J. Hyslop for comments on the manuscript. The views expressed are those of the authors and not necessarily those of the institutions or organisations involved.

\section{References}

Araújo LOD, Gonçalves LC, Rezende ASC, Rodriguez NM \& Maurício RM (1997) Digestibilidade aparente em equiídeos submetidos a dieta composta de concentrado e volumosos, fornecido com diferentes intervalos de tempo (Apparent digestibility in equids of diets differing in concentration and volume when fed over different time periods). Arquivo Brasilerio de Medicina Veterinaria e Zootecnia 49, 225-237.

Association of Official Analytical Chemists (1990) Official Methods of Analysis of the Association of Analytical Chemists, 
15th ed. Arlington, VA: Association of Official Analytical Chemists.

Crozier JA, Allen VG, Jack NE, Fontenot JP \& Cochran MA (1997) Digestibility, apparent mineral absorption and voluntary intake by horses fed alfalfa, tall fescue and caucasian bluestem. Journal of Animal Science 75, 1651-1658.

Cuddeford D \& Hyslop JJ (1996) Intake and digestibility of a high fibre concentrate offered ad libitum to ponies and donkeys. In Proceedings of the European Association for Animal Production 47th Annual Meeting, Lillihammer, Norway, p. 296, Abstr. Norway: EAAP.

Cuddeford D, Pearson RA, Archibald RF \& Muirhead RH (1995) Digestibility and gastro-intestinal transit time of diets containing different proportions of alfalfa and oat straw given to Thoroughbreds, Shetland ponies, Highland ponies and donkeys. Animal Science 61, 407-417.

Cymbaluk NF (1990) Comparison of forage digestion by cattle and horses. Journal of Animal Science 70, 601-610.

Dulphy JP, Martin-Rosset W, Dubroeucq H, Ballet JM, Detour A \& Jailler M (1997a) Compared feeding patterns in ad libitum intake of dry forages by horses and sheep. Livestock Production Science 52, 49-56.

Dulphy JP, Martin-Rosset W, Dubroeucq H \& Jailler M (1997b) Evaluation of voluntary intake of forage trough-fed to light horses. Comparison with sheep. Factors of variation and prediction. Livestock Production Science 52, 97-104.

Ellis RNW \& Lawrence TLJ (1980) The energy and protein requirements of the light horse. British Veterinary Journal 136, 116-121.

Fernadez-Rivera S, Midou A \& Marichatou H (1994) Effect of food allowance on diet selectivity and intake of pearl millet (Pennisetum glaucam) stover leaves by sheep. Animal Production 58, 249-256.

Fuller Z, Cox JE \& Argo CMcG (1998) Photoperiodic entrainment of seasonal changes in appetite and growth in pony colts. Proceedings of the British Society of Animal Science 36, 131.

Haenlein GFW, Holdren RD \& Yoon YM (1966) Comparative response of horses and sheep to different physical forms of alfalfa hay. Journal of Animal Science 25, 740-743.

Hyslop JJ, Jessop NS, Stefansdottir GJ \& Cuddeford D (1997) Comparative degradation in situ of four concentrate feeds in the caecum of ponies and the rumen of steers. In Proceedings of the 15th Equine Nutrition and Physiology Symposium, Ramada Plaza, Fort Worth, Texas, USA, pp. 116-117. [Equine Nutrition and Physiological Society, editors]. Savoy, IL: The Equine Nutrition and Physiology Society.

Hyslop JJ, Tomlinson AL, Bayley A \& Cuddeford D (1998) Voluntary feed intake and apparent digestibility in vivo in ponies offered a mature threshed grass hay ad libitum. Proceedings of the British Society of Animal Science, 36, 130.

Izraely H, Chosniak I, Stevens CE, Demment MW \& Shkolnik A (1989a) Factors determining the digestive efficiency of the domesticated donkey (Equus asinus asinus). Quarterly Journal of Experimental Physiology 74, 1-6.

Izraely H, Chosniak I, Stevens CE \& Shkolnik A (1989b) Energy digestion and nitrogen economy of the domestic donkeys (Equus asinus asinus) in relation to food quality. Journal of Arid Environments 17, 97-101.

Janis C (1976) The evolutionary strategy of the Equidae and the origins of rumen and caecal digestion. Evolution 30, 757-774.

Mueller PJ, Hintz HF, Pearson RA, Lawrence PR \& Van Soest PJ (1994) Voluntary intake of roughage diets by donkeys. In
Working Equines, pp. 137-148 [M Bakkoury and A Prentis, editor]. Rabat: Actes Editions.

National Research Council (1989) Nutrient Requirements of Horses, Washington, DC: National Academy Press.

Pearson RA (1998) The future of working equids - prospects and problems. In Proceedings of the Third International Colloquium on Working Equines, October 5-9 1998, Universidad Nacional Autonoma de Mexico, Mexico City, Mexico, pp. 1-20 [Facultad de Medicina Veterinaria y Zootecnia, editors]. Mexico City: Universidad Nacional Autonoma de Mexico.

Pearson RA \& Merritt JB (1991) Intake, digestion and gastrointestinal transit time in resting donkeys and ponies and exercised donkeys given ad libitum hay and straw diets. Equine Veterinary Journal 23, 339-343.

Pearson RA, Archibald RF \& Muirhead RH (1998) The effect of level of feeding on digestibility of oat straw and alfalfa given to ponies and donkeys In Proceedings of the Third International Colloquium on Working Equines, October 5-9 1998, Universidad Nacional Autonoma de Mexico, Mexico City, Mexico, pp. 286-292 [Facultad de Medicina Veterinaria y Zootecnia, editors]. Mexico City: Universidad Nacional Autonoma de Mexico.

Pearson RA, Cuddeford D, Archibald RF \& Muirhead RH (1992) Digestibility of diets containing different proportions of alfalfa and oat straw in thoroughbreds, Shetland ponies, Highland ponies and donkeys. Proceedings of the First European Conference on Equine Nutrition. Pferdeheilkunde Sondersgabe, September 1992, pp. 153-157.

Ruckebusch Y (1984) Motricité digestive chez les équidés (Digestive motility in the equid). In Le Cheval: Reproduction, Selection Alimentation, Exploitation, pp. 173-188 [R Jarrigeand and W Martin-Rosset, editors]. Paris: INRA.

Savadogo M, Zemmelink G \& Nianogo AJ (2000) Effect of selective consumption on voluntary intake and digestibility of sorghum (Sorghum bicolor L. Moench) stover, cowpea (Vigna unguiculata L. Walp.) and groundnut (Arachis hypogaea L.) haulms by sheep. Animal Feed Science and Technology 84, 265-277.

Smith DG (1999) The impact of grazing time allowance on the dry matter intake and foraging behaviour of cattle and donkeys managed under traditional African grazing systems. PhD Thesis, University of Edinburgh.

Suhartanto B, Julliand V, Faurie F \& Tisserand JL (1992) Comparison of digestion in donkeys and ponies. Proceedings of the First European Conference on Equine Nutrition. Pferdeheilkunde Sondersgabe, September 1992, pp. 158-161.

Tisserand JL, Faurie F \& Toure M (1991) A comparative study of donkey and pony digestive physiology. In Donkeys, Mules and Horses in Tropical Agricultural Development, pp. 67-72 [D Fielding and R.A Pearson, editors]. Edinburgh: Centre for Tropical Veterinary Medicine, University of Edinburgh.

Todd LK, Sauer WC, Christopherson RJ, Coleman RJ \& Caine WR (1995) The effect of feeding different forms of alfalfa on nutrient digestibility and voluntary intake in horses. Journal of Animal Physiology and Animal Nutrition 73, 1-8.

Uden P, Rounsaville TR, Wiggans GR \& Van Soest PJ (1982) The measurement of liquid and solid digesta retention in ruminants, equines and rabbits given timothy (Phleum pratense) hay. British Journal of Nutrition 48, 329-339.

Van Soest PJ (1994) Nutritional Ecology of the Ruminant, 2nd ed. Ithaca, NY: Cornell University Press. 